\title{
Elemental and biochemical composition of Nephrops norvegicus (Linnaeus 1758) larvae from the Mediterranean and Irish Seas
}

Received: 25 January 2004 / Revised: 25 May 2004 / Accepted: 27 May 2004

(C) Springer-Verlag and AWI 2004

\begin{abstract}
The Norway lobster, Nephrops norvegicus, is a commercially exploited decapod which is widely distributed throughout the north-eastern Atlantic and the Mediterranean Sea. Ovigerous females originating from the Mediterranean and the Irish Seas were held in the laboratory until larvae hatched. Biomass and biochemical composition, as well as digestive gland structure, were examined in newly hatched larvae from these two regions. In addition, previously published data from a North Sea population were included in our comparison. Elemental analyses showed that the absolute quantities of dry mass $(\mathrm{DM})$, carbon $(\mathrm{C})$, nitrogen $(\mathrm{N})$ and hydrogen $(\mathrm{H})(\mathrm{col}-$ lectively referred to as $\mathrm{CHN}$ ) per individual, and the $\mathrm{C}: \mathrm{N}$ mass ratios, were significantly lower, while the relative CHN, protein and lipid values (in \% of DM) were higher in samples from the Irish Sea compared to larvae originating from either the Mediterranean or the North Sea. As in $\mathrm{CHN}$, the absolute level of protein per individual was higher in larvae from the Mediterranean, while no significant differences were observed in the individual lipid contents. Likewise, the digestive gland structure at hatching did not show any differences between study ar-
\end{abstract}

Communicated by H.-D. Franke

G. Rotllant $(\bullet) \cdot$ F. Sardà

Institut de Ciències del Mar (CMIMA-CSIC),

Passeig Marítim de la Barceloneta 37-49, 08003 Barcelona, Spain e-mail: guiomar.rotllant@irta.es

Tel.: +34-977745427

Fax: +34-977744138

K. Anger

Biologische Anstalt Helgoland (AWI),

27483 Helgoland, Germany

M. Durfort

Departament de Biologia Cellular,

Universitat de Barcelona,

Av. Diagonal 645, 08028 Barcelona, Spain

Present address:

Centre d'Aqüicultura, IRTA,

Carretera del Poble Nou, s/n Km 5.5, Sant Carles de la Ràpita,

43540 Tarragona, Spain eas. Intraspecific variability in biomass and chemical composition of newly hatched larvae from different regions may be related to differential patterns of reproduction in regions with different climatic conditions. Lobster larvae hatch in the Mediterranean Sea predominantly in winter when both water temperature and planktonic food availability are at a minimum, while hatching in the Irish Sea occurs under more favourable conditions in spring. Hence, significantly higher wet mass, dry mass and protein values in Mediterranean larvae may represent adaptive traits allowing for early posthatching survival and development under food-limited conditions in an oligotrophic environment.

Keywords Biochemical composition $\cdot$ Larvae $\cdot$ Nephrops norvegicus $\cdot$ Mediterranean - Irish Sea

\section{Introduction}

The commercial fisheries of the Norway lobster, $\mathrm{Ne}$ phrops norvegicus (Linnaeus, 1758), are economically important in Europe. N. norvegicus is a benthic decapod found in waters from the Mediterranean to Iceland. Reproduction varies latitudinally, with egg incubation ranging from 6 months in the Mediterranean to more than 10 months in Iceland, and hatching occurring at the end of winter or early in spring (Sardà 1995).

The first larval stage of $N$. norvegicus was morphologically described by Sars $(1884,1890)$ from Norwegian waters, by Jorgensen (1925) from the northeastern coast of England, and by Santucci (1926 a, 1926b, 1926c, 1927) from the Tyrrhenian Sea, showing great similarity among geographically separated populations. The larvae from different areas appear to hatch with similar initial size. Larval presence and distribution has been studied from a fisheries point of view in different regions including Iceland (Eiriksson 1970), the Faroe Islands (Andersen 1962), Scotland (Fraser 1965), Danish waters (Poulsen 1946), the Irish Sea (Horsburgh et al. 2000; Briggs et al. 2002, and earlier papers cited therein), England (e.g. 
Milligan and Nichols 1988), the North Sea (Rees 1952) and the Adriatic (Karlovac 1953).

Laboratory experiments have demonstrated that temperature is the major factor regulating the duration of larval development (Figueiredo 1971; Figueiredo and Vilela 1972; Thompson and Ayers 1989; Dickey-Collas et al. 2000a). In the Irish Sea, temperature increases during the hatching period from ca. $6^{\circ} \mathrm{C}$ to $13^{\circ} \mathrm{C}$, while larval stage duration decreases (Dickey-Collas et al. 2000b). Figueiredo (1971) and Figueiredo and Vilela (1972) reared $N$. norvegicus larvae in the laboratory at different salinities (33-40\%o), but the larvae seemed to be unaffected within the tested range.

The large range of geographic-climatic distribution of this species, from cold-temperate North Atlantic to subtropical Mediterranean regions, raises the question whether there are intraspecific differences in larval biomass or chemical composition. Such data are relevant for the development of bioenergetic models of growth and survival, and for the future selection of brood stock for restocking and aquaculture.

\section{Methods}

Ovigerous Norway lobster females were collected by local fishermen using bottom-trawl boats in front of Barcelona harbour (Mediterranean Sea) and creels in Strangford Lough (Irish Sea). They were transported alive to Barcelona (Spain) and Portaferry (North Ireland) laboratories, respectively. They were maintained in individual containers $(50 \mathrm{l})$ at $13 \pm 1^{\circ} \mathrm{C}$ and $37.5 \pm 1 \%$ o (Barcelona) or at $11 \pm 1^{\circ} \mathrm{C}$ and $34.5 \pm 1 \%$ (Portaferry) until the first larval stage hatched, 1-2 weeks after collection of the females.

Freshly hatched larvae from each of 20 different females (eight originating from the Mediterranean Sea and 12 from the Irish Sea) were sampled within about $12 \mathrm{~h}$ of hatching. Samples were briefly rinsed in distilled water, blotted on fluff-free filter paper, and wet mass (WM) was measured to the nearest $0.01 \mathrm{mg}$ using an Ohaus AP250D-0 digital balance. Thereafter, the material was stored at $-80^{\circ} \mathrm{C}$ for later elemental and biochemical analyses. Five replicate analyses were made for each measurement of biochemical and elemental composition, while total wet mass was determined in $n=10$ larvae per female. Additional larvae were fixed in Bouin for histological studies. Fixed larvae were later embedded in paraffin, and sections were stained with hematoxylin-eosin dye. The cell types occurring in the hepatopancreas were classified according to the criteria given by Hirsch and Jacobs (1930), extended by Al-Mohanna and Nott (1987) and adapted by Sagristà and Durfort (1991).

The ash content was determined in $n=5$ replicate larvae per female: after dry mass (DM) measurement, the samples were combusted for $16 \mathrm{~h}$ at $500^{\circ} \mathrm{C}$, cooled in a desiccator, and weighed again. Dry mass (DM) and ash content were measured to the nearest $0.1 \mu \mathrm{g}$ on a Mettler UM 3 balance.

Before $\mathrm{CNH}$ analysis, the samples were transported frozen at $-56^{\circ} \mathrm{C}$ to the Helgoland Marine Biological Station, Germany, where we freeze-dried them overnight in a GT 2 (Leybold-Heraeus) apparatus. Larvae were subsequently combusted at $1020^{\circ} \mathrm{C}$ in a CHN analyzer (Carlo Erba Science, Model 1108, Version Fisons).

Homogenates in distilled water of two larvae per female were prepared for lipid and protein determinations. Total lipids were measured with a Merckotest 3321 kit, total protein with the Bradford (1976) method using a Bio-Rad kit.

Arithmetic means and standard deviations were calculated from ten replicate wet mass determinations and from five replicate elemental and biochemical analyses. The significance of differences between mean values of larvae from the Mediterranean and Irish
Sea was tested using a one-way analysis of variance (ANOVA) with untransformed data and a probability level $P<0.05$.

\section{Results}

Biomass data (WM, DM, water content of WM, ash, and CHN per individual) of freshly hatched larvae originating from females fished in the North Sea (Anger and Püschel 1986), the Mediterranean, and the Irish Sea are compared in Fig. 1. Irish Sea larvae had significantly lower biomass values per individual, and the $\mathrm{C}: \mathrm{N}$ mass ratio was lower, compared to larvae from the Mediterranean and the North Sea (Fig. 1). Nevertheless, the percentage $\mathrm{C}$ and $\mathrm{N}$ contents (as fractions of DM) were higher in Irish Sea larvae than in those from the other two areas (Fig. 2). WM, water, ash, and CHN contents of larvae from the Mediterranean Sea were slightly lower than those from the North Sea; however, these differences were not statistically significantly (Fig. 1).

Protein and lipid contents were not measured in North Sea larvae. In the other populations, the protein fraction showed the same pattern as the CHN values. In Irish Sea larvae, the protein content per individual was lower, while the percentage values were higher than in larvae from the Mediterranean. The absolute lipid content was similar in larvae originating from the two areas, but the relative values (\% of DM) were significantly higher in larvae from the Irish Sea (Fig. 3).

The histological study of the digestive gland showed that the majority of cells (75\%) belong to the A type. They are cubic, with a diameter of ca. $14 \mu \mathrm{m}$. The secretory cells represent $10 \%$ of the total. This type of cell is glandular, belonging to the calciform group. The secretory cells are $35-40 \mu \mathrm{m}$ high and $10 \mu \mathrm{m}$ wide. The rest of the cells $(10-15 \%)$ are undifferentiated and their diameter is around $10 \mu \mathrm{m}$. In the digestive cells, no differences were observed between larvae from different origins but embryos close to hatching and adults had larger digestive cells than the larvae after hatching (Fig. 4).

\section{Discussion}

This study suggests that larvae originating from the North Sea and the Mediterranean were larger and richer in lipids, proteins, and CHN per individual than those from the Irish Sea. Considering oceanographic data from these areas (see http://www.sea-search.net) and assuming that phytoplankton blooms may be expressed in terms of chlorophyll $a$, we suggest that temperature and food availability should be key factors for larval hatching and development in $N$. norvegicus. Different populations of the Norway lobster spawn in late winter, spring and early summer (cf. Sardà 1995). N. norvegicus is considered to be originally a subarctic species which has been able to adapt to warmer climates. In the Mediterranean Sea, its larvae hatch in winter when surface water temperature is 
Fig. 1 Nephrops norvegicus, North Sea (black bars), the Mediterranean (white bars), and the Irish Sea (grey bars): biomass (wet mass, WM); water content (\% of WM); dry mass (DM); ash; carbon; nitrogen and hydrogen contents per individual. Arithmetic means \pm SD (error bars); $n=10$ individuals for $\mathrm{WM}, \% \mathrm{WM}$ and $\mathrm{DM}$ values, and $n=5$ individuals for ash and $\mathrm{CNH}$ values. Different letters near error bars indicate statistically significant differences between larvae from different regions (ANOVA; $P<0.05$ ) freshly hatched larvae from the
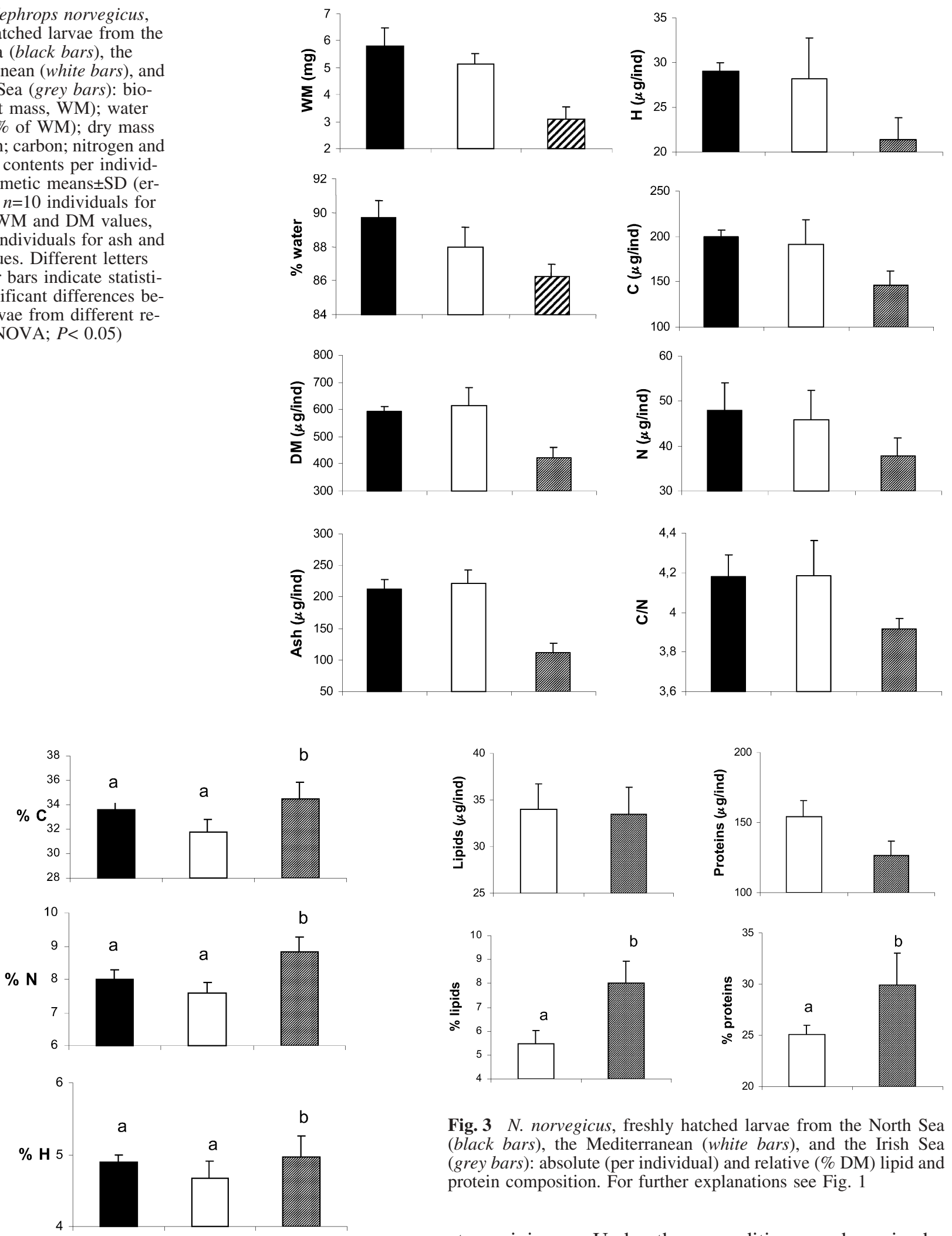

Fig. $2 N$. norvegicus, freshly hatched from the North Sea (black bars), the Mediterranean (white bars), and the Irish Sea (grey bars): relative proportions (in \% DM) of carbon, nitrogen and hydrogen. For further explanations see Fig. 1
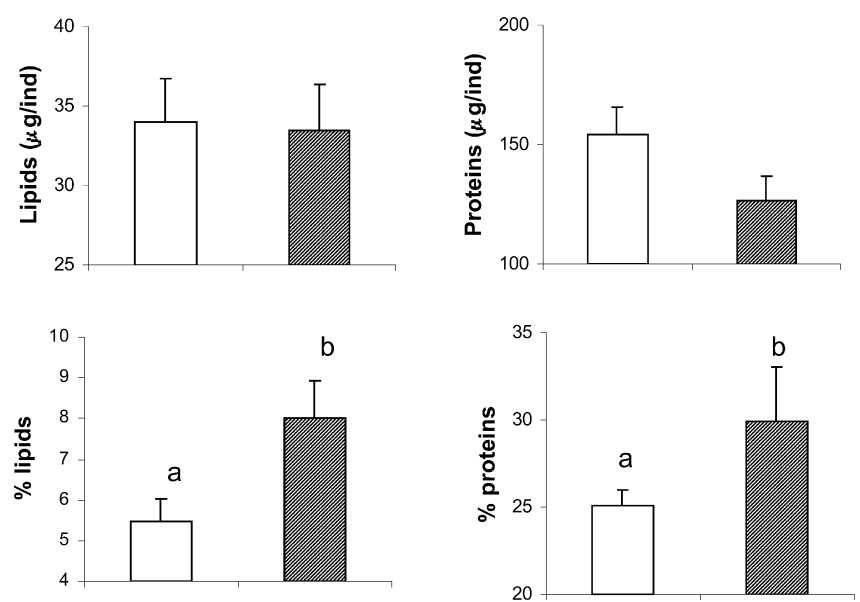

Fig. 3 N. norvegicus, freshly hatched larvae from the North Sea (black bars), the Mediterranean (white bars), and the Irish Sea (grey bars): absolute (per individual) and relative (\% DM) lipid and protein composition. For further explanations see Fig. 1

at a minimum. Under these conditions, embryonic development lasts about 6-7 months, while settlement occurs under summer conditions. Since chlorophyll $a$ peaks do not occur before spring, the early larvae hatch and develop in a nutritionally poor environment. This is in contrast to larvae from northern Europe, where hatching 
Fig. 4a-d Histological sections of the digestive gland of $N$. norvegicus: a larva from the Mediterranean; b larva from the Irish Sea; c embryo from the Mediterranean; and $\mathbf{d}$ adult from the Mediterranean. $\mathbf{a}, \mathbf{b}$ and $\mathbf{d}$ stained with hematoxylineosin dye, c with Masson trichrome dye; $\times 180$
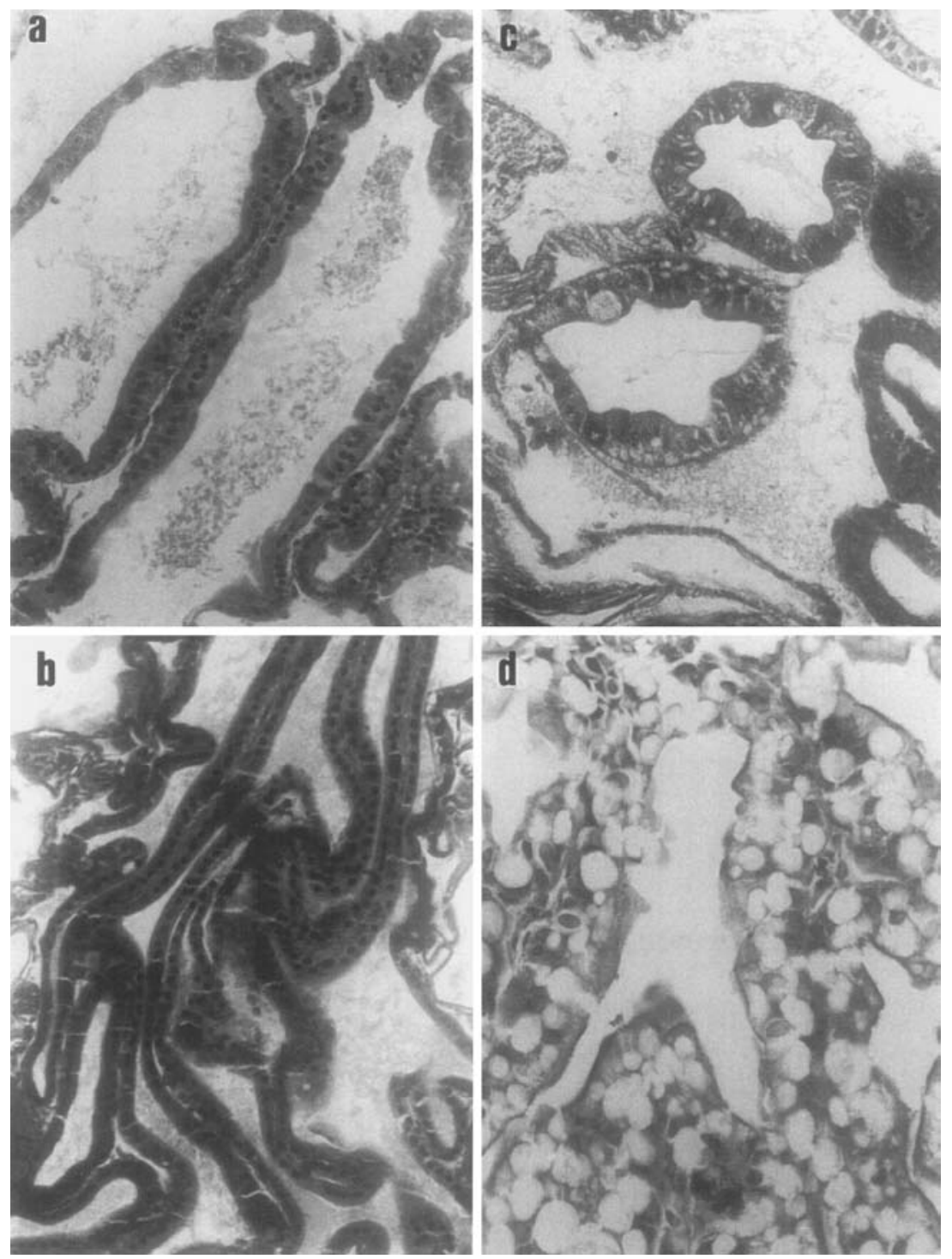

coincides with a period characterised by thermal stratification and the beginning of a phytoplankton bloom. Our results demonstrate that larvae from the Mediterranean Sea hatch with significantly higher wet mass, dry mass and protein content per individual than larvae from the Irish Sea. These traits appear to indicate higher initial energy reserves in the former, which may allow for survival of early larval stages in an oligotrophic environment such as the Mediterranean during winter. Since the absolute amounts of lipid per larva were similar in these two populations, our data suggest that proteins, rather than lipids, represent the predominant energy pool for development under conditions of food limitation.

Although the North Sea shows on average higher chlorophyll $a$ concentrations during the hatching period, larvae from this region presented similar biomass values to those originating from the Mediterranean Sea. However, this comparison is based on only a single hatch from the North Sea versus eight from the Mediterranean, so that no final conclusions can be drawn from the available data.

Tuck et al. (1997) studied the biochemical composition of adult $N$. norvegicus in relation to ovary maturation, comparing females from Scottish and Mediterranean waters. They did not observe significant differences in the lipid or water content of the ovary, while the percentage protein and carbohydrate values were higher at stations where lobsters grew faster. The hepatopancreas did not show any significant interpopulational differences in lipid, protein or carbohydrate contents. Similarly, in the present study we observed no differences in the digestive gland structure of larvae originating from different regions. Hence, the structure of the digestive gland does not appear to be a good indicator of the nutritional condition in newly hatched larvae, although it is considered to be adequate in adults. Feeding studies in homarid lobsters demonstrate that larvae may not recover from nutritional stress if food is not provided soon after hatching (Anger et al. 1985; Aiken and Waddy 1995; Rotllant et al. 2001). 
Therefore, the initial larval biomass and elemental or biochemical composition at hatching should be an important variable determining the tolerance of nutritional stress occurring early in development.

Acknowledgements The authors would like to thank Dr. N. McQuaid for providing larvae from the Irish Sea, Ms. C. Püschel and Mr. J.A. García for CHN analyses and other technical support, and the captains and crews of the fishing vessels Maireta III, Francesc i Lluis and Zorrilla from Barcelona harbour. This study was supported by the Centre de Referència de Recerca i Desenvolupament en Aqüicultura de la Generalitat de Catalunya.

\section{References}

Aiken DE, Waddy SL (1995) Aquaculture. In: Factor JR (ed) Biology of the lobster Homarus americanus. Academic Press, San Diego, USA, pp 153-176

Al-Mohanna SY, Nott JA (1987) R cells and the digestive cycle in Penaeus semiculcatus (Crustacea:Decapoda). Mar Biol 95:129137

Andersen FA (1962) The Norway lobster in Faeroe waters. Medd Dan Fisk Havunders 3:265-326

Anger K, Püschel C (1986) Growth and exuviation of Norway lobster (Nephrops norvegicus) larvae reared in the laboratory. Ophelia 25:157-167

Anger K, Storch V, Anger V, Capuzzo JM (1985) Effects of starvation on moult cycle and hepatopancreas of stage I lobster (Homarus americanus) larvae. Helgol Meeresunters 39:107116

Bradford M (1976) A rapid and sensitive method for the quantitation of microgram quantities of protein utilizing the principle of protein-dye binding. Anal Biochem 72:248-254

Briggs RP, Armstrong MJ, Dickey-Collas M, Allen M, McQuaid N, Whitmore J (2002) The application of fecundity estimates to determine the spawning stock biomass of Irish Sea Nephrops norvegivus (L.) using the annual larval production method. ICES J Mar Sci 59:109-119

Dickey-Collas M, Briggs RP, Armstrong MJ, Milligan SP (2000b) Production of Nephrops norvegicus larvae in the Irish Sea. Mar Biol 137:973-981

Dickey-Collas M, McQuaid N, Armstrong MJ, Allen M, Briggs RP (2000a) Temperature-dependent stage durations of Irish Sea Nephrops larvae. J Plankton Res 22:749-760

Eiriksson H (1970) On the breeding cycle and fecundity of the Norway lobster at south-west Iceland. ICES CM1970/K 6:1-3

Figueiredo MJ (1971) Sobre a cultura de crustaceaos decapodes em laboratorio: Nephrops norvegicus (Lagostim) e Penaeus kerathurus (Camarao). Bol Inform Inst Biol Marit 1:1-17

Figueiredo MJ, Vilela MH (1972) On the artificial culture of $\mathrm{Ne}$ phrops norvegicus reared from the egg. Aquaculture 1:173-180

Fraser JH (1965) Larvae of Nephrops norvegicus in the Scottish area, 1935-1964. ICES CM1965 (Shellfish Cttee., att. Plankton Cttee.) 10:186-189
Hirsch GC, Jacobs W (1930) Der Arbeitsrhytmus der Mitteldarmdrüse von Astacus leptodactylus. Z Vergl Physiol 12:524-558

Horsburgh KJ, Hill AE, Brown J, Fernand L, Garvine RW, Angelico MMP (2000) Seasonal evolution of the cold pool gyre in the western Irish Sea. Prog Oceanogr 46:1-58

Jorgensen OM (1925) The early stages of Nephrops norvegicus, from the Northumberland Plankton, together with a note on the post-larval development of Homarus vulgaris. J Mar Biol Assoc UK 13:870-879

Karlovac O (1953) An ecological study of Nephrops norvegicus (L.) of the high Adriatic. Izv Inst Oceanogr Ribarstvo Rep 5(2C): $1-50$

Milligan SP, Nichols JH (1988) Nephrops larvae surveys off the north-east coast of England in 1987. ICES CM 1988/K 5:1-13

Poulsen EM (1946) Investigations on the Danish fishery for and the biology of the Norway lobster and the deep prawn. Rep Dan Biol Stn 48:27-49

Rees CB (1952) Continuous plankton records: the Decapod larvae in the North Sea, 1947-1949. Hull Bull Mar Ecol 3(22):157184

Rotllant G, Charmantier-Daures M, Charmantier G, Anger K, Sardà F (2001) Effects of diet on Nephrops norvegicus (L.) larval and postlarval development, growth, and elemental composition. J Shell Res 20:347-352

Sagristà E, Durfort M (1991) Membranous tubular system in R-cells of decapod hepatopancreas investigated using electronopaque tracers. Cell Tissue Res 226:585-590

Santucci R (1926a) Lo sviluppo post-embrionale dello Scampo (Nephrops norvegicus (L.)) del Quarnero. Boll Mus Zool Anat Comp Univ n a 6(2):7-10

Santucci R (1926b) Lo sviluppo post-embrionale dell'aragosta (Palinurus vulgaris Latr.) e dello scampo (Nephrops norvegicus (L.)). Boll Mus Zool Anat Comp Univ n a 6(6):31-33

Santucci R (1926c) Lo sviluppo e d'ecologia post-embrionali dello "Scampo, (Nephrops norvegicus (L.)) nel Tirreno e nei mari nordici. R. Comit Talassogr Ital 125:3-34

Santucci R (1927) Uno stadio di sviluppo non ancora descritto dello "Scampo,, (Nephrops norvegicus (L.)). R. Comit Talassogr Ital 128:1-6

Sardà F (1995) A review (1967-1990) of some aspects of the life history of Nephrops norvegicus. ICES Mar Sci Symp 199:7888

Sars GO (1884) Bidrag til Kundskaben on Decapodrnes Forvandlinger I. Nephrops, Calocaris, Gebia. Arch Math Naturv 9:155-204

Sars GO (1890) Bidrag til Kundskaben on Decapodrnes Forvandlinger 2. Lithodes, Eupagurus, Spiropagus, Galathodes, Galathea, Munida, Procellana, Nephrops. Arch Math Naturv 13:133-201

Thompson BM, Ayers RA (1989) Laboratory studies on the development of Nephrops norvegicus larvae. J Mar Biol Assoc UK 69:795-801

Tuck I D, Chapman CJ, Atkinson RJA (1997) Population biology of the Norway lobster, Nephrops norvegicus (L.) in the first of cycle, Scotland: growth and density. J Mar Sci 54:125-135 